NBER WORKING PAPER SERIES

\title{
SEARCH AND DELIBERATION IN \\ INTERNATIONAL EXCHANGE: LEARNING \\ FROM MULTINATIONAL TRADE ABOUT \\ LAGS, DISTANCE EFFECTS, AND HOME BIAS
}

\author{
Subramanian Rangan \\ Robert Z. Lawrence \\ Working Paper 7012 \\ http://www.nber.org/papers/w7012
NATIONAL BUREAU OF ECONOMIC RESEARCH 1050 Massachusetts Avenue
Cambridge, MA 02138
March 1999

We have benefited from conversations with numerous colleagues at INSEAD and Harvard, and from comments received in seminars at Harvard University's Center for Business and Government, and London Business School's Strategic Leadership Research Program. In particular, we thank Antonio Fatas, Martin Gargiulo, Ranjay Gulati, Mun Ho, Bjorn Lovas, Renée Mauborgne, F. M. Scherer, Marla Tuchinsky, Raymond Vernon, Shang-Jin Wei, and Xueguang Zhou for their valuable time and feedback, and Raghu Rau for research assistance. This paper reflects work done for a Brookings Institution project Corporate Responses to the Dollar financed by the Sloan Foundation which will be published as Rangan and Lawrence (1999). Any opinions expressed are those of the authors and not those of the National Bureau of Economic Research.

(-) 1999 by Subramanian Rangan and Robert Z. Lawrence. All rights reserved. Short sections of text, not to exceed two paragraphs, may be quoted without explicit permission provided that full credit, including ${ }^{\circledR}$ notice, is given to the source. 
Search and Deliberation in International Exchange:

Learning from Multinational Trade

About Lags, Distance Effects, and Home Bias

Subramanian Rangan and Robert Z. Lawrence

NBER Working Paper No. 7012

March 1999

JEL No. F14, F15, F23

\section{ABSTRACT}

This paper compares the responses of intra- and extra-firm trade to exchange rate changes. It does so both to inform the debate on whether these responses are qualitatively different and to improve understanding of the microfoundations of features of trade behavior such as long adjustment lags, the large impact of distance, and the presence of significant home bias. We argue that the informational problems posed by search (acts identifying potential exchange partners) and deliberation (acts assessing their reliability and trustworthiness) play a key role in explaining these features and suggest that multinationals should have advantages in overcoming these problems. Indeed we find that the responses of multinationals to exchange rate changes are both larger and more rapid.

Subramanian Rangan

INSEAD

Bld de Constance

Fontainebleau

France 77305

subramanian.rangan@insead.fr

Robert Z. Lawrence

Kennedy School of Government

Harvard University

Cambridge, MA 02138

and NBER

robert lawrence@harvard.edu 


\section{Search and Deliberation in International Exchange: Learning from Multinational Trade About Lags, Distance Effects, and Home Bias}

In this paper we compare the responsiveness of U.S. multinational enterprises' intrafirm trade to U.S. arm's length trade to changes in the real exchange rate. We do for three reasons. One aim is to shed new light on the long debated question of whether MNEs' trade responses are stickier than arm's length trade. ${ }^{1}$ Existing views on intrafirm trade fall in two camps: one that believes intrafirm trade is or ought to be no different from arm's length trade, ${ }^{2}$ and one that believes that such trade is less responsive than arm's length trade. ${ }^{3}$ Proponents of the latter view predict slow and small responses for MNEs because intrafirm behavior, they argue, reflects hierarchical or command behavior and is not likely to be as sensitive to market considerations as arm's length transactions. In contrast, we will argue that MNEs ought to respond faster and more vigorously, not because of special access to cross-border production capacity, but rather because of information advantages arising out of multinational operations.

$1 \quad$ See Bergsten, Horst, and Moran (1978: esp. chapter eight).

2 See Bergsten, Horst, and Moran (1978); Caves (1996).

3 See Goldsbrough (1981); Helleiner (1981:3); Little (1986:46); Cho(1990); and Encarnation (1992). Gerald Helleiner (1981: 3), has written that intrafirm trade "can and usually do[es] take place in consequence of central commands rather than in response to price signals..." Likewise, Little (1986: 46) has argued that "Because intra-firm trade is potentially 'managed' trade...the pace or size of its adjustment" differs "from that of trade between unaffiliated firms." Goldsbrough (1981: 573) argues that trade flows generated by the location decisions of a firm with large fixed investments in several countries may not respond as rapidly to shifts in relative prices as those of an independent producer...unconcerned with the effect of its actions on the profitability of overseas affiliates. 
Our second aim is to suggest some microfoundations for three extensively documented macro patterns that have puzzled international economists. The first puzzle pertains to the presence of long lags in trade responses to exchange rates. Even when exchange rate changes cause large and "permanent" shifts in relative prices, the geographic distribution of economic activity shifts only slowly and hesitatingly. Established buyer-supplier relationships appear sticky and switching is lagged. How might we explain these considerable lags and, moreover, why when national incomes rise or fall, does international trade adjust both without long lags and more vigorously?

The second puzzle pertains to the disproportionately large dampening effect that physical distance appears to have on bilateral trade. The puzzle, as many observers have noted, is that distance effects appear to be far greater than what might be explained by transport costs alone. The third puzzle, and the one that has sparked the most interest recently, pertains to the "home bias" in international trade and finance. One well-known study (McCallum, 1995) examined the trade effects of the seemingly "innocuous" U.S.-Canada border on the grounds that "if borders didn't matter" this one must provide the prototypical case. ${ }^{4}$ But, after controlling for market size and comparative advantage, this study found that in 1988, the year of the data, Canadians were 22 times more likely to trade with fellow Canadians than with persons equally distant but residing in the United States. Other studies (e.g., Wei, 1996) have reported smaller quantitative effects, but they too support the consensus that there is a marked home bias in economic activity.

While these empirical quandaries have stimulated new bouts of economic theorizing, unifying and satisfactory explanations have eluded economists. Paul R.

4 John McCallum (1995), "National borders matter: Canada-U.S. regional trade patterns," American Economic Review, June, 85 (3): 615-623. 
Krugman and Richard Baldwin (1987) have suggested that economists' macro models lack plausible micro foundations. Echoing these views, trade theorist Gene Grossman (1998: 31) avers that, "[These macro patterns lead] me to believe that something is missing from our trade models, be they of the Hecksher-Ohlin or Dixit-StiglitzKrugman variety. It seems we need models where distance (and common polity, and common language, and common culture) play more of a role. I suspect this is a model with imperfect information, where familiarity declines rapidly with distance..."

In the course of addressing our first question about the relative speed and vigor with which MNEs respond to exchange rate changes, we will, in this chapter, suggest a tentative hypothesis that resonates with the preceding views and offers some plausible micro foundations to the puzzling macro patterns just described. The hypothesis is built around a line of generalization that can be sketched as follows: In pursuing cross-border economic opportunities, firms engage in a process of search and deliberation. Search refers to acts involved in identifying potential exchange partners, and deliberation refers to acts involved in assessing their reliability and trustworthiness. Search grows more important the more spatially dispersed economic opportunities become, and deliberation grows more important the more costly it becomes to reverse allocative actions or their effects. In many instances, institutions--such as organized markets and rating agencies--and innovations--such as advertising and warranties-have emerged to relieve the problems of search and deliberation, and, in these instances, firms can readily pursue the economic opportunities they perceive.

However, in international trade and investment such institutions and innovations don't exist or don't work well enough. Search and deliberation remain problematic and firms, because of the resulting information insufficiency, exhibit a 
great deal of stickiness and lagged (or progressive) adjustment in responding to apparent cross-border economic opportunities. In these circumstances, firms often turn to their business and social networks, because, frequently, those networks can help alleviate problems of search and deliberation and enable firms to uncover and exploit cross-border economic opportunities.

If this line of argumentation is valid, then, by extension, in the domain of international economic exchange, firms that are embedded in well-elaborated social and business networks will tend to enjoy information advantages by virtue of which they will adapt and respond more proficiently to new economic opportunities. In particular, relative to their purely domestic counterparts, MNEs will tend to be embedded abroad in better-elaborated social networks. This latter characteristic ought to provide MNEs with relative information advantages (vis-à-vis the problems of search and deliberation), and, in turn, on the back of these information advantage MNEs ought to exhibit speedier and more vigorous import responses.

In the sections that follow, we will flesh out the concepts of search and deliberation, and discuss, within that frame, multinationals' potential network advantages. In the subsequent section, we will contrast empirically multinational and non-multinational enterprises' international trade responses to exchange rate changes. To anticipate, after controlling for industry, partner country, income effects, and certain other variables, we find that relative to arm's length trade, MNEs' intrafirm trade exhibits both speedier and larger responses to common real exchange rate changes. In our discussion, we will consider alternative explanations for our empirical findings.

We will conclude by proposing some speculative micro-macro linkages between the problems of search and deliberation, the economic behavior of firms, and 
the puzzling macro patterns we alluded to above. Our sense is that at the current pace, the trends of regionalization and globalization will tend to "shrink the globe" and dampen distance and border effects. Still, considering how profound cross-border information discontinuities appear to be, we would speculate that distance, and, particularly, border effects in economic exchange, will persist noticeably well into the future. Of course, to the extent the proportion of multinationals in the population of firms grows (and there are some reasons to anticipate this), information discontinuities will be better patched and a deeper integration across distance and borders will be fostered.

\section{THE PROBLEMS OF SEARCH AND DELIBERATION}

By "search" we refer to acts involved in identifying potential exchange partners. Firms engage in search when they sense that response to a perceived economic opportunity or threat involves action that might lie outside the pattern of current activities and exchange relationships. In general, search grows more problematic the more spread out potential exchange partners are. Organized markets exist in many undifferentiated commodities, but even there, trading companies have had to emerge to link supply with remote demand. As for differentiated goods and goods made to order, smaller volumes and deliberation problems have tended to keep markets local, national, or regional.

In any event, regardless of the nature of the commodity, search problems are primarily a function of spatial dispersion. A corollary is that distance erodes economic exchange; distance "always shows up as a crucial determinant of trade" (Krugman, 1995: 1273). Importantly, "shipping costs are quite small for most goods that can be shipped at all; yet trade falls off quite strongly with distance." 
Let us turn now to the problem of deliberation. By "deliberation," we refer to acts involved in assessing the reliability and trustworthiness of potential exchange partners. Like search, deliberation is also an information intensive process. But, if search is aimed at reducing incomplete information about the present, deliberation is aimed at reducing incomplete information about the present and especially the future. Deliberation is a non-issue if actors can be certain or nearly certain about: (i) the quality of what is to be exchanged, and (ii) the manner in which exchange partners will discharge mutual obligations in the future. But in the absence of certainty, deliberation enters the picture and it grows more important the more costly it becomes to reverse allocative actions or their effects. When actors think deliberation is important but problematic, they will tend to act reluctantly and progressively. In such circumstances, economic actions are unlikely to be influenced by relative prices alone.

Indeed, even in the face of changes in relative prices, buyer-supplier relationships are often noted to be sticky. A good part of the explanation is known to lie in the fact that in many buyer-supplier relationships switching-out and switching-in are costly (Webster and Wind, 1972; Sheppard and Tuchinsky, 1996). As in labor markets, assessing the reliability, timeliness, and capabilities of a new exchange partner is a process of discovery. As this process of discovery unfolds the buying firm might be: (i) placing in circulation a stock of inferior products that upon discovery will be costly to recover and upgrade (e.g., the recall of vehicles fitted with defective components); (ii) developing costly-to-reverse dependencies with the new supplier (as might happen when a firm turns over the management of its computer and information systems to an outside vendor); and (iii) closing-off a return to previous exchange partners since the latter are likely to have tied up with other customers or even exited the business altogether. These are some of the key drivers of uninsurable costs that 
firms are bound to weigh before switching or settling upon exchange partners. As these drivers gain salience, firms will sense a greater need to obtain reliable information about a potential exchange partner. If, however, the requisite information cannot be assembled, firms are wont to forego potential profit opportunities. Economic opportunities, like proverbial "dollar bills on the sidewalk," will lie waiting to be picked up.

In circumstances where search and deliberation are problematic, business and social networks tend to assume significance in shaping and explaining economic actions and outcomes. Gould's (1994) study of immigrants' trade effects provides an illustration. Gould (pp. 302-303) notes that immigrants bring many things with them, "perhaps key among these being...ties or links...[back] to their home country..." These social ties, he notes, "can lower...[the] costs associated with obtaining foreign market information and establishing trade relationships." Gould hypothesizes that immigrants' social ties ought to lead to a "direct increase in [trade] between the host and home countries," and he finds support for this view in his empirical analysis.

Correspondingly, the information advantages posited in Granovetter's (1985) notion of embeddedness are especially pertinent to the problem of deliberation. Recall that, to large extent, deliberation involves an attempt to resolve incomplete information about the future behavior of exchange partners. In this endeavor, it is natural that we look to exchange partners' antecedents, because, rightly or wrongly, we believe past behavior can offer us valuable clues about future behavior. It follows then that embeddedness can aid deliberation because the confidence with which we can assess the reliability and trustworthiness of a potential exchange partner tends to be much higher when we ourselves or someone we know well has had "concrete personal 
relations" with the actor in question (see Gulati, 1995; Portes and Sensenbrenner, 1995; Uzzi, 1997).

\section{SEARCH AND DELIBERATION IN INTERNATIONAL TRADE}

For most managers around the world, family and community ties, school and university ties, banking and boardroom ties, chamber of commerce and trade association ties, and ties to employers and co-workers, all tend to be largely local or national. As a result, more than distance, language, and culture separates managers and the firms they work in from counterparts residing outside their national borders. Indeed, distance and borders engender information discontinuities.

By implication, the problems of search and deliberation are undoubtedly magnified in economic exchange that must occur across national borders. Indeed, studies on international exchange and organizational buying confirm this latter contention (see Webster and Wind, 1972; Egan and Moody, 1992; Gulati, 1995; Martin, Mitchell, and Swaminathan, 1995; Gordon and Bovenberg, 1996). A recent review article (Liang and Parkhe, 1997: 510-511) notes that, "Domestic vendor selection is more often a 'choice' situation... International vendor selection, on the other hand, often is a 'search' situation, where the information processing load has a higher probability of exceeding the bound of human rationality." "Often the favored search approach is simply to call and rely upon a known contact for a recommendation [Liang and Stump, 1996]; objective information available in government sources is largely ignored [Min and Galle, 1991]” (p. 509).

Deliberation too is a problem of considerable proportions in international exchange. U.S. importers who participated in one interview-based study expressed that they "prefer long-term, stable, and direct relationships because [such relationships] 
"make good business sense"” (Egan and Moody, 1992: 325). "Finding and evaluating" new suppliers abroad is costly, buyer-supplier mutual learning (what we termed cospecialization) is "cumulative," and any "mutual obligation and trust develops incrementally." International buyers, this study noted, "are therefore reluctant to lose this advantage and start over with new partners" (p. 325). The fingerprints of costlyto-reverse allocative actions are clearly visible here. Further, consistent with our embeddedness arguments, "When evaluating potential suppliers, virtually all buyers first seek information within their own network...of product-specific buyers and suppliers... The first source of information is the personal judgement of other buyers." Finally, given that both search and deliberation are problematic in international trade, by our earlier reasoning, we would anticipate that the price mechanism does not operate too well in economic activity that occurs across national borders. As we noted at the top of the chapter, this contention too receives empirical support: price dispersion, lagged adjustment, and visibly modest price elasticities have been persistent quandaries in international trade (see Krugman and Baldwin, 1987; Lawrence, 1990; Engel and Rogers, 1996).

If international economic exchange is encumbered by the problems of search and deliberation, then we would anticipate actors embedded in well-elaborated crossborder networks to exhibit relatively greater and speedier responses to international economic opportunities. This, in a nutshell, is why we would expect multinationals' trade responses to exchange rate changes to be speedier and more vigorous than trade that occurs at arm's length.

\section{MULTINATIONALS' INFORMATION ADVANTAGES}


Multinational enterprises, by virtue of the fact that they operate in two or more countries, have the potential of being simultaneously embedded in two or more distinct social networks (Kogut, 1983; Ghoshal and Bartlett, 1990). Most established MNEs have actualized this potential by developing concrete relations with local suppliers, customers, labor, and financial institutions. These external ties are supplemented to lesser or greater extents by internal ties within the MNE (usually at least between the headoffice and the various foreign affiliates). According to one empirical study of the “information sources" used by U.S. MNE managers, "When a headquarters executive in an $[\mathrm{MNE}]$ acquires external information, the most likely single source of this information is the corporation's own staff abroad (Keegan, 1974: 414)." Internal ties among managers in an MNE emerge from both formal and informal interaction, rotation, and other socialization processes (Edstrom and Galbraith, 1977; Prahalad and Doz, 1987; Bartlett and Ghoshal, 1989). This no doubt costly investment has long been thought to place the MNE in an advantageous position vis-à-vis nonmultinational enterprises (Vernon, 1979; Kogut, 1983; Dunning and Rugman, 1985; Lessard, 1986).

The sequence of events that leads to the possession of this advantage can be described as follows: an MNE locates and operates facilities in another advanced country when demand for its products in that country (and the neighboring region) grows sizable and is served best through a local facility. Routine operation of the foreign facility generates a set of business relationships and a continually replenished stock of information about actual prices, the existence, location, and precise needs and capabilities of buyers and, importantly, suppliers in that region. In his early study of U.S. multinationals' expansion abroad, Knickerbocker (1973: 26) put it thus: 
When firm A starts to manufacture in country $\mathrm{X}$, its subsidiary management, and perhaps its headquarters management, are exposed to factor inputs and technologies that may differ in terms of type, quality, or cost from those previously encountered in the United States or elsewhere. In responding to this new matrix of factors, firm A may find that it can use new raw materials, or it may devise new manufacturing processes, or it may even uncover new product possibilities. Moreover, information about the discoveries can be transferred to other parts of A's organization.

Of course, experiences are likely to vary quite a bit across firms and locations; it can hardly be otherwise. But, in general, over time, there will be a tendency for the MNE to become embedded in the host environment.

Against this setting, imagine that in response to a change in exchange rates the MNE's home facility wants to explore the feasibility and economics of sourcing intermediate inputs from the foreign country. The MNE's home facility ought to be able to do so relatively easily because the search and deliberation necessary to exploit the new economic opportunity is likely to be behind it. The MNE's purely domestic counterparts, on the other hand, will tend to confront a more difficult situation because information and connections required to operate at home are invariably different from that required for buying and selling abroad. Moreover, local presence is frequently a necessary condition for exchanging information reliably and for settling transactions under advantageous terms (Keegan, 1974; Egan and Moody, 1992).

This is not to say that non-multinationals working via arm's length relationships will have no trade responses. On the contrary, given the growing intensity of competition, the large size of exchange rate changes over the last years, and the fact that international trade existed long before anyone heard of multinational enterprises, we fully anticipate non-multinationals to respond and there is a voluminous empirical research that tells us they do (Stern, Francis, and Schumacher, 1976). But, relative to their purely domestic counterparts, MNEs will tend to be embedded abroad in better-elaborated social networks. This characteristic of better structural and 
relational embeddedness ought to provide MNEs with information advantages (vis-àvis the problems of search and deliberation), and, in turn, on the back of these information advantage MNEs ought to exhibit speedier and more vigorous import responses. The reasons for greater speed are obvious, and the reasons for greater vigor can be stated as follows: As argued earlier, deliberation problems tend to weaken firms' willingness to substitute on the basis of price. Relative to non-multinational enterprises, MNEs, for reasons just laid out, face smaller deliberation problems. Other things equal then, MNEs ought to exhibit higher exchange rate elasticities. Further, the costs of search and deliberation can be considered as additive to the purchase price (Stigler, 1961). Firms that face higher net prices will tend to trade smaller volumes than those that face lower net prices. By this logic too, MNEs ought to exhibit higher exchange rate elasticities.

\section{EMPIRICAL ANALYSIS}

The spirit of the analysis to be conducted is as follows. Using the United States as the focal country, let us pick an industry, partner country, and a time period. Having done that, let us examine in the industry and period chosen the speed and elasticity with which U.S. imports from that partner country respond to changes in the U.S. dollar's real exchange rate (vis-à-vis the currency of that partner country). Let us now compare the results so obtained to estimates of the same coefficients in the same industry, partner country, and time period, but for U.S. imports from U.S. multinationals that have operations in that partner country. Controlling for industry, country, and time period in this manner, we should, according to our hypothesis, observe that U.S. imports from MNEs exhibit statistically larger elasticities (i.e., greater responses) and shorter lags (i.e., speedier responses) in adapting to the 
common real exchange rate changes. To be sure, any observed differences will be consistent with our search and deliberation story only if we can rule out MNE advantages that arise from other important sources such as their size and sophistication. We will, therefore, attempt to control for these potentially confounding factors.

\section{Data Sources and Coverage}

Data used in the analysis come from three sources: the U.S. Department of Commerce, the OECD, and the IMF. Industry by country by year U.S. import data were obtained from the U.S. Department of Commerce. Nominal exchange rates are from the IMF's International Financial Statistics. GDP data and industry-andcountry-specific producer prices (that are used to calculate industry-by-countryspecific real exchange rates) are from the OECD's Indicators of Industrial Activity. Data on R\&D expenditure are from the OECD (1997) publication entitled Research and Development in Industry. Estimates of U.S. importers' employment size (used as an indicator of U.S. importers' firm size) are based upon employment figures reported in the OECD (1997) publication entitled Globalisation and Small and Medium Enterprises: Volume 2. All data pertaining to U.S. multinationals are from the U.S. Bureau of Economic Analysis' (BEA) annual surveys of the operations of U.S. multinationals and their foreign affiliates. Since these latter data are available only on an annual basis, the analysis below is conducted only on annual data (using averages in the case of exchange rates and year-end data for all other variables).

Coverage is guided primarily by the availability of data (particularly on the operations of U.S. multinationals). Accordingly, the analysis below pertains to U.S. imports between 1977 and 1994 of manufactured goods in four industries--food and 
related products, chemicals and allied products, non-electrical machinery, and electric and electronic products, and from nine countries--Australia, Canada, France, Germany, Italy, Japan, Netherlands, Switzerland, United Kingdom. U.S. imports in the four industries from the nine countries accounted in 1994 for $\$ 123$ billion or a little over a fifth of all U.S. manufacturing imports in that same year. U.S. MNEs' intrafirm imports accounted for a 10 to 15 percent share of that total. Depending on the specification estimated, the number of observations range from around 300 to one thousand. The lower limit is driven by the U.S. MNE data which frequently are missing. In particular, between 1979-1981 the BEA did not conduct surveys of U.S. MNEs' foreign operations; therefore, MNE data for those three years are unavailable.

Nevertheless, by focusing on U.S.-headquartered MNEs we gain an important advantage deriving from the fact that by 1977, the first year covered in our study, these entities had already established operations in Europe, Canada, Australia, and Japan. In fact, according to the data, between 1977 and 1994, the number of U.S. MNE parents in manufacturing actually declined slightly from 1,842 to 1,543 (perhaps not inconsistent with the consolidation that has taken place domestically); and the number of foreign affiliates of these parents in the nine countries of interest declined slightly as well (mainly in Canada) going from 11,771 to 11,189 (USDIA 1977: Tables, B and C; USDIA 1994: Tables II.A.1 and II.A.2). This relative stability in MNE affiliates abroad ought to mitigate concerns about both shifts in the composition of the sample and any potential simultaneity bias. Moreover, in the industries and countries we are studying, less than 10 (typically less than 5) percent of the output of U.S. firms' foreign affiliates is destined for shipment back to United States. The point being, these affiliates were not set up as low-cost export platforms to serve the U.S. market, rather their priority from the start has been to serve local and regional markets abroad. This 
assures us that our sample data are not biased in favor of the hypotheses we will be exploring.

It must be noted here, that although the MNE trade figures used in this study are the only set reported on a country-by-industry basis, these data are primarily intrafirm trade data. Of the U.S. imports originated by U.S. MNEs' foreign affiliates nearly 80 percent are shipped to the U.S. parent. As we mentioned above, according to existing views, intrafirm trade ought to be no different from arm's length trade, or it ought to be less responsive than arm's length trade. Yet, since MNE intrafirm trade is likely to embody both internal and external ties and benefit from the hypothesized information advantages, we expect U.S. intrafirm imports to be more responsive, ceteris paribus.

\section{Dependent Variable}

In working with international trade we have, in principle, a choice to focus on imports or exports. Although the latter is often the focus of empirical and policy oriented research, in our case, it is not as suitable as imports. The reason for this is straightforward: multinational enterprises are, in a sense, identified innately with exports and success in export markets (Vernon, 1966; Dunning, 1974; Caves, 1996). Hence, by sticking to imports we avoid biasing the results in favor of MNEs. For instance, in the case of imports, there is no destination-market advantage to be had by MNEs. Purely domestic firms ought to be equally "at home" in the United States. Further, since the United States is a more open economy than most, U.S. imports are likely to be a better register (than exports) of responses to new international economic opportunities. In other words, by selecting imports, variation in the dependent variable is likely to be enhanced. 
Accordingly, the dependent variable used in the analysis is the $\log$ of U.S. imports from a particular country in a given industry and year. Ideally, we would want to state imports in volume terms, however, since country and industry-specific import prices are not available, we use nominal import value figures. Other empirical studies (e.g., Junz and Rhomberg, 1972; Lawrence, 1990) have also employed this approach noting that the magnitude of the reported elasticities will be greater in absolute terms. Since we will use nominal figures for both MNEs and overall U.S. imports, this should not throw off our comparative analysis. Of course, transfer prices emerge as a potential issue and we will discuss it below.

\section{Independent Variables}

The first independent variable of interest is the real exchange rate (which is stated in terms of foreign currency units per U.S. dollar). We want to examine both the magnitude of the elasticity and the pattern of lags exhibited by U.S. MNEs and average U.S. importers in responding to the level of this independent variable. While most studies tend to use exchange rates that are simply averaged across countries, we measure this variable in country, industry, and year specific terms. For instance, in the case of U.S. imports of chemicals from Germany, we construct the real exchange rate by adjusting the mark-dollar nominal rate to reflect producer prices in the U.S. and German chemical industries. In this manner, we construct an index of real exchange rates for the years 1977 through 1994 and use it in log terms in the analysis.

Another independent variable of interest is the interaction term between the real exchange rate and an MNE dummy variable. In regressions that pool MNE and average-U.S. importer responses, we would anticipate the coefficient on this interaction term (MNE*exchange rate) to be positive and statistically significant. That 
is, after controlling for industry, year, partner country, and other variables stated below, MNEs, by virtue of their information advantages, ought to exhibit greater responsiveness to the level of the exchange rate than the average (non-multinational) U.S. importer.

\section{Control Variables}

There are several control variables that warrant inclusion in our analysis. First, we want to recognize that the decisions of U.S. firms to source inputs from abroad are influenced not only by exchange rates, but also by changes in the levels of their business activity. We, therefore, include as a control variable price-adjusted U.S. industry-specific GDP (gross domestic product). This is an important variable in its own right, but here it gives us added insight, because, when their activity levels change, organizations (we assume) need to simply adjust quantities purchased up or down, they do not switch suppliers and they do not have to search or deliberate.

According to our hypothesis, in the absence of search and deliberation, adjustment should be prompt and vigorous. We would anticipate, therefore, that any lags on the activity variable would be shorter than those observed on exchange rates. And, without ruling out other causes for this, we would also anticipate that the coefficient on this variable to be larger than the coefficient on exchange rates.

Importantly, to the extent that MNEs trade better internationally by virtue of their greater experience, size, and sophistication, we should pick this up in an MNE*GDP interaction term. By our theory, a positive coefficient on this interaction term would suggest the presence of advantages not related to superior networks and information. Accordingly, the MNE*GDP coefficient could serve as a crude control 
against which we can compare the $\mathrm{MNE}^{*}$ exchange rate coefficient (anticipating the latter to be larger and more significant than the former).

To control separately for firm size, we include a firm size*exchange rate interaction term because larger firms (read MNEs) can more readily justify the costs of having on their staff exchange rate specialists and persons proficient in foreign languages. Also, to the extent search and switching costs are fixed they will be more easily borne by large rather than small firms. Finally, large firms will tend to possess greater experience and expertise in successfully executing the logistics called for in international trade. On the other hand, it is well known that size can be a mixed blessing: large firms are more susceptible to "internal opportunism" and inter-divisional "logrolling" both of which can impede flexibility and responsiveness (Williamson, 1975). Large firms are also more likely to be unionized and this may influence their ability and willingness to substitute home content with imports. Lastly, large size might confer scale economies that make short-run adjustments suboptimal. In any event, we use the average number of employees per U.S. firm in a given industry and year as an indicator of firm size. Employment figures are not available for U.S. importers; so, instead, we use estimates based on figures for U.S. exporters. For MNEs, the figures used are average MNE employment by industry. These data are also entered in $\log$ terms in the firm size*exchange rate interaction term. (Note, firm size is not entered by itself as an independent variable since it introduces perfect collinearity with the industry dummies in any given year and industry.)

We also enter a time trend in the regressions to account for advances in technology, the rise in capabilities abroad and the attendant rise in competition, and greater liberalization in the world economy. Further, to control for unobserved influences, we include dummy variables for eight out of the nine countries and three 
out of the four industries. In the regressions, then, the constant term stands for the omitted country and industry, which, in our case, will be the United Kingdom and machinery.

Lastly, in some models (that we don't report here) we included R\&D/Sales ratios as a control. Research intensity is believed to influence international trade--at least exports (see Dunning, 1993; Kobrin, 1991). Since U.S. imports from country X are country X's exports to the U.S., we controlled for foreign (i.e., country X's) industry-specific R\&D/Sales ratios. Since research efforts typically take time to get reflected in new products and increased sales, we entered this variable on a two-year lagged basis. Including this variable did not change the results (and neither did alternative lag structures, including zero lags on R\&D/Sales).

\section{Model Estimation and Results}

Equations explaining U.S. imports are estimated as variations of the following specification:

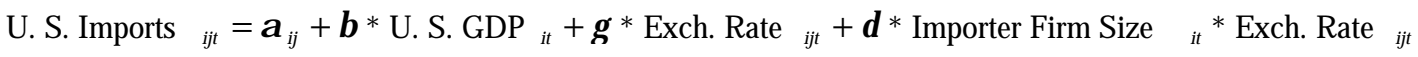

$$
\begin{aligned}
& +\varepsilon * \text { Time }_{t}+\zeta * \text { Lagged Foreign R } \quad \& \text { D/Sales }_{i j t}+\eta * \operatorname{MNE}_{i j t} * \text { Exch. Rate }_{i j t}+\theta_{i j t} \text {. }
\end{aligned}
$$

The subscripts $i, j$, and $t$, stand, respectively, for industry, country, and year. With the exception of the time trend (and the $\mathrm{R} \& \mathrm{D} / \mathrm{Sales}$ ratios) all variables are entered in natural logs. The coefficients on these latter variables, therefore, represent the elasticity of U.S. imports to a one percent increase in the respective independent variables. Pooling observations across industries and countries violates normal OLS assumptions. To correct bias in parameter estimates, a least squares dummy variable 
approach is adopted. Such fixed-effects models constrain the coefficients on the independent variable to be the same across observations, but they allow unobserved cross-sectional heterogeneity to be captured in the different intercepts. This approach is well suited to panel datasets that, like ours, are "short and wide" (Greene, 1990: 482-485).

Tables 1 presents the first set of results. Consider the estimates under columns 1 and 2 in Table 1. These models include the GDP, exchange rate, firm size, and the country and industry dummy variables. The first equation explains U.S. overall-meaning MNE and non-MNE related--imports from the nine countries in the four industries over the 1977-1994 period. The second equation explains U.S. imports originating from U.S. MNEs' foreign affiliates. In both equations, the coefficients on U.S. GDP are, as anticipated, positive, relatively large (around 2), and statistically significant. On the other hand, the coefficient on the (contemporaneous) real exchange rate is positive but not statistically significant for U.S. overall imports; however, for MNE imports, this coefficient is positive, significant, and larger than the coefficient on the GDP variable. When a time trend is added to these models (not shown), the pattern of the exchange rate coefficients remains unchanged. However, not surprisingly, the time trend cancels out much of the effect associated with the rise in GDP. As indicated by the adjusted $R$-squares on these models--of 0.61 and 0.77 --the models explain a significant amount of the variation in the dependent variable.

The models in the other columns in Table 1 explore the question of relative speed of adjustment. The results in those columns suggest clearly that MNEs exhibit speedier responses. Consider the models in columns 3 and 4 in Table 1. Both those models contain the contemporaneous and one-year lagged exchange rates. The oneyear lagged exchange rate coefficient for U.S. overall imports now assumes statistical 
significance. This is also the case for MNE imports, although, contemporaneous exchange rates continue to be large and statistically significant. When two-year lagged exchange rates are introduced (in columns 5 and 6 of Table 1), their coefficients assume significance for both U.S. overall and MNE imports. However, the sum of the exchange rate coefficients shows a marked difference between U.S. overall and MNE imports: for the former they sum up to 0.97 , while for the latter, they sum up to 4.31 . (When a lagged GDP term was added to the models in columns 5 and 6 in Table 1, it did not take on a statistically significant coefficient.)

In Table 2, we pool the overall and MNE-only observations and estimate regressions with interaction terms between the MNE dummy variable and the price and activity variables. In this table, we also explore the robustness of our results by running regressions on selected sub-samples of the available data. First, let us note that the MNE*real exchange rate interaction term is positive and statistically significant in all the models shown in Table 2. That is, MNEs with operations in the partner country exhibit a greater responsiveness to the level of the exchange rate than the average U.S. importer does. Also, in this pooled sample (see column 1, for instance), the coefficient on the contemporaneous exchange rate assumes statistical significance. The coefficients on the GDP are also significant and relatively much larger (in the absence of the time trend), and the adjusted $R$-square for the model in column 1 is (at 0.73 ) quite satisfactory.

Now in many of the industry-country-years, especially for MNEs, import values were small. Upon inspection, we discovered that out of the nine countries in the study, three--Australia, Italy, and Switzerland--had fragmentary and relatively small trade figures. To see whether these were driving the results, we ran a regression excluding Australia, Italy, and Switzerland, and the results are presented in column 2 
of Table 2. As indicated in that column, the $\mathrm{MNE}^{*}$ exchange rate coefficient retains statistical significance and, in fact, rises in magnitude.

Next, in order to further explore MNE size and sophistication as sources of superior MNE adjustment, we included an MNE*GDP interaction variable to the model just reviewed. As column 3 of Table 2 shows, the MNE*GDP interaction term is positive and statistically significant. This finding supports the view that MNEs enjoy adjustment advantages that might derive from greater international experience, and superior communication and logistics capabilities. Yet, the coefficient on $\mathrm{MNE}^{*}$ exchange rate interaction term is much larger than that on MNE*GDP $(2.24$ compared to 0.51$)$. Further, the appropriate $t$ - and $F$-tests based upon restricted and unrestricted regressions (not shown) indicate that the coefficients are statistically different from one another. Running the model shown in column 3 with all available observations (see results in column 4 of Table 2) weakens the difference between the two coefficients but does not alter the basic finding. (The same holds true for specifications that exclude the firm size*exchange rate interaction term).

Next we ran regressions to see whether MNEs' information advantages were becoming more visible over time. We present the results of those regressions in Table 3. Given that trade has liberalized quite significantly over the past two decades, one might anticipate that multinationals have been able to better use their information advantages over this time frame and have grown more responsive. Indeed, this view receives mild support in the results shown in column 2 of Table 3 (see, in particular, the coefficient on $\mathrm{MNE}^{*}$ real exchange rate*time).

Further, since technology has advanced and "selection pressures" are likely to have ratcheted up over the past twenty years, it would appear that, notwithstanding search and deliberation problems, the relative price (i.e., exchange rate) responsiveness 
of all firms ought to have trended up. This view too is supported by the positive and statistically significant coefficient on the real exchange rate*time interaction term in column 3 of Table 3. Running a model with both interaction terms (see column 4), maintained the results but reduced to 13 percent the significance of the coefficient on the $\mathrm{MNE}^{*}$ real exchange rate*time interaction term.

In separate industry-by-industry regressions (not reported here, see Rangan, 1998), the MNE*exchange rate interaction term was positive for all four industries and statistically significant in three (with the exception of machinery). The unreported results of one more set of regressions merits mention. In order to check whether the search and deliberation hypothesis holds even in the absence of MNE-related data, we ran regressions using only overall U.S. import data. Reasoning that search and deliberation ought to be relatively easier for U.S. importers when they have to switch away from foreign suppliers back to U.S. suppliers, we examined whether the exchange rate coefficient was larger during dollar depreciations (say during the 198690 period) than dollar appreciations (say during the $1979-85$ period). Not only was the contemporaneous exchange rate coefficient larger during depreciations (1.51 compared to 0.43 during appreciations), it was also statistically significant at the 5 percent level. (The other coefficients took predictable values. $)^{5}$

5 Two other points also merit mention. First, to explore the so-called "quantum effect," we added the absolute magnitude of the exchange rate change in some of our regressions. Consistent with the findings summarized in Goldstein and Khan (1985: 1075), this variable did not take a statistically significant coefficient nor did it change the results. Second, we acknowledge that exchange rate expectations do not figure in our regressions. We assume all exchange rate changes are "permanent." However, we might note that to the extent expectations about exchange rate are important, we have no reason to believe the MNEs and non-MNEs form systematically different expectations. Further, if the "temporariness" of exchange rate changes might be gauged by the volatility in exchange rate changes, then exchange rate changes don't appear to have become more temporary. Volatility (measured as the standard deviation of monthly percentage changes) in exchange rates of G7 economies between 1980-85, 1986-89, 1990-94 was 1.7, 1.7, and 1.6 


\section{ALTERNATIVE EXPLANATIONS AND DISCUSSION}

We set out to understand first whether MNEs' intrafirm trade is stickier relative to arm's length trade. Our empirical results clearly indicate that this is not the case. In fact, consistent with our arguments about MNEs' information advantages visà-vis the problems of search and deliberation, the results indicate that even on imports MNEs exhibit speedier and more vigorous responses to changes in real exchange rates.

To be sure, MNEs tend to enjoy internalization and experience advantages, and, indeed, we found that the MNE*GDP coefficient took positive and significant values. But, we also found that the MNE*exchange rate interaction coefficient took much larger values, and this would support our contention that problematic search and deliberation and MNEs' information advantages are key explanators here. We also found that the average firm size*exchange rate variable took either a statistically insignificant or a significant but negative coefficient. This finding is likely to be explained by the presence of scale economies, but it also supports a view expressed in a recent OECD study on globalization (1997, Vol. 1: 54): "Size does hold some importance, especially in successfully taking the first steps to internationalisation, but once there, it does not seem to matter much...[S]maller size can often be an advantage."

Of course, the internalized trade issue does raise the question of transfer prices. Intrafirm MNE transactions are typically made at internal transfer prices and internal exchange rates that tend to be rigid (Lessard, 1986). But if transfer prices tend to remain stable in originating country currency terms and if company internal exchange rates lag actual exchange rates (say because of the presence of currency hedge

respectively (see The Economist, October 7, 1995, Survey pg. 28). So volatility is unlikely to be useful as an independent variable in our regressions. 
contracts), then, ceteris paribus, MNE import values will register smaller not bigger changes. (In fact, in our data, the simple correlation coefficient between MNE imports and exchange rates is close to zero.) MNE transfer pricing practices cannot, therefore, account for our findings. Indeed, they would strengthen our findings and explanation.

There are two other related alternative explanations that merit discussion. First, we have not included capacity in our regressions in this chapter. But, as Krugman and Baldwin (1987) point out, if capacity considerations were important, then they ought to be manifested in lags on income effects. This is not the case and we can, hence, rule out capacity as a key explanatory variable. A related alternative explanation might argue that although capacity constraints may not play a role, it might be that multinationals have more compatible capacity across geographies and, therefore, they are able to exploit relative price differences better. But in other research (see Rangan and Lawrence, 1999: Chapter 3), we have explored this question of compatibility, and we found that (due to their historical local-for-local strategies) even multinationals' production capacities were not (over the 1977-94 period) characterized by a high degree of cross-border compatibility.

Last, but not least, there is a growing body of empirical work (based on data unrelated to the MNE trade figures we have used) that is also reporting findings that are consistent with our emphasis on the importance and advantages of business networks in international trade (see Williamson, 1986; Gould, 1994; Rauch, 1997).

As for the puzzling macro patterns alluded to at the top of this paper, we have suggested that lags and progressiveness in trade responses to exchange rates emerge from search and deliberation problems. Observed distance effects, we would argue, are primarily a manifestation of search problems. In other words, distance tends to make search for potential exchange partners more cumbersome. The presence of 
organized markets is likely to mitigate search problems. By implication, distance ought to dampen relatively more trade in goods (such as differentiated manufactures) that are not offered on organized exchanges. Physical distance is also likely to have declined in importance over the past couple of decades since search is likely to have become easier and less expensive over this period. These hypotheses receive support in some recent and carefully done analysis by James E. Rauch (1997).

As far as border and home bias effects, we view these as primarily a function of deliberation problems (or, contrariwise, as a manifestation of a familiarity bias). Now if it were true, as would seem plausible, that trade in differentiated products represents economic action that is more costly to reverse than trade in commodities, then network effects ought to be relatively greater for differentiated products. Again, we refer the reader to Rauch (1997), wherein he reports empirical results that are consistent with our arguments and expectations. Rauch (1997: 28) notes, "The coefficient on colonial ties are always positive, significant, and largest for the differentiated commodity group in every year..."

A last piece of interesting evidence on these matters appears in a European Commission survey conducted in mid-to-late 1995 to assess the effect on company strategies of the EC '92 Single European Market initiative. Of particular interest to us was the response of the firms to questions on their intra-European sourcing strategies. As shown in Table 4, with the exception of the purchase of raw materials, the vast majority of the $(13,500)$ responding firms did not view the removal of intra-European border barriers as important to their sourcing strategies. Interestingly, the figures under "very important" and "quite important" decline predictably as they go from raw materials, to components, to business services, to financial services. This pattern is more or less what one would expect to see if one believed that the importance of 
deliberation rises, as we believe it does, when one goes from raw materials to components to services. To be sure, we would anticipate that if the survey were repeated a few years hence, the percentage of respondents selecting the very and quite important columns would rise, but the declining pattern across the rows is likely to persist.

\section{CONCLUSION}

When the identification and/ or assessment of potential exchange partners is problematic, a situation of information insufficiency obtains and firms will appear reluctant to pursue apparent economic opportunities. These problems of search and deliberation tend to become salient when economic opportunities are dispersed spatially or when economic actions or their effects are perceived as costly to reverse.

When brought into the international setting, these simple ideas can help us understand why certain parts of our global economy (such as currency markets) appear extremely volatile and responsive while other parts (such as trade in manufactured goods) exhibit visible stickiness and lagged adjustment. Speculating further, we have positioned in a search-deliberation framework the major types of economic activity that span national borders (see Figure 1). If distance is a proxy for search problems, and borders are a proxy for deliberation problems, then, for example, we would expect short lags and relatively small distance effects in portfolio investment. However, we would expect international portfolio investments to exhibit large border (or home bias) effects. As Rauch (1997) has remarked, foreign direct investment (FDI), on the other hand, is to portfolio investment what trade in differentiated products is to trade in commodities. 
What might we say about the future? In our opinion, the technology of the Internet has the potential to significantly ameliorate search problems. We might therefore anticipate that distance effects will, in the future, more closely reflect transport costs. However, we anticipate the familiarity bias to persist: Between two trading partners equal in every respect except familiarity, firms will choose to conduct business with the more familiar one. So border effects and path dependence are very likely to remain visible. Again, the Internet might help deliberation problems. But, in our opinion, it is unlikely that such amelioration will be rapid or dramatic. On the other hand, a protracted period of trade and investment liberalization accompanied by a rising multinationalization of firms is likely to temper cross-border deliberation problems. To sum up, we expect that border effects and the home bias will diminish in the future, but they will hardly disappear. Above-normal price dispersion is, therefore, likely to persist. After all, in most markets, trust and price are likely to remain complements and not turn into substitutes. 


\section{REFERENCES}

Bergsten, C. Fred, Thomas Horst, and Theodore H. Moran, 1978. Washington, D.C.: The Brookings Institution.

Caves, Richard E., 1996. Multinational enterprise and economic analysis: Second edition. USA: Cambridge University Press.

Cho, Kang Rae, 1990. "The role of product-specific factors in intra-firm trade of U.S. manufacturing multinational corporations." Journal of International Business Studies, 21 (2): 319-330.

Dunning, John H., 1974. Economic analysis and the multinational enterprise. London: Allen \& Unwin.

Dunning, John H. and Alan Rugman. 1985. “The influence of Hymer's dissertation on theories of foreign direct investment." American Economic Review, 75 (May): 22832 .

Dunning, John H., 1993. Multinational enterprises and the global economy. UK: Addison-Wesley.

Edstrom, A. and J. R. Galbraith, 1977. "Transfer of managers as a coordination and control strategy in multinational organizations." Administrative Science Quarterly, 22: 248-263.

Egan, Mary Lou, and Ashoka Mody, 1992. "Buyer-seller links in export development." World Development, 20 (3): 321-334.

Engel, Charles and John H. Rogers, 1996. "How wide is the border?" American Economic Review. 86: 1112-1125.

Ghoshal, Sumantra and Christopher A. Bartlett, 1990. "The multinational corporation as an interorganizational network." Academy of Management Review, 15 (4): 603625 .

Gordon, Roger H. and A. Lans Bovenberg, 1996. "Why is capital so immobile internationally? Possible explanations and implications for capital income taxation." American Economic Review, December, 86 (5): 1057-1075.

Gould, David M., 1994. "Immigrant links to the home country: empirical implications for U.S. bilateral trade flows." The Review of Economics and Statistics, May, 76 (2): 302-316.

Granovetter, Mark, 1985. "Economic action and social structure: the problem of embeddedness." American Journal of Sociology, November, 91 (3): 481-510. 
Greene, William H., 1990. Econometric analysis. New York: Macmillan Publishing Company.

Grossman, Gene M., 1998. Comment on Alan V. Deardorff, "Determinants of bilateral trade: Does gravity work in a neoclassical world?", in Jeffrey A. Frankel (ed.), The regionalization of the world economy, Chicago: NBER and the University of Chicago Press, pp. 29-31.

Gulati, Ranjay, 1995. "Does familiarity breed trust? The implications of repeated ties for contractual choice in alliances." Academy of Management Journal, 1995, 38 (1): 85-112.

Helleiner, Gerald K., 1978. "Transnational corporations and trade structure: the role of intra-firm trade." In Giersch, Herbert (ed.), On the economics of intra-industry trade, Tübingen: J.C.B. Mohr, Paul Siebeck (159-181).

Hymer, Stephen H. The International Operations of National Firms: A Study of Direct Investment. PhD thesis, Cambridge: MIT Press.

IMF Statistics Department, 1997. International Financial Statistics Yearbook: Vol. L. Washington, D.C.: International Monetary Fund Publication Services.

Junz, Helen B., and Rudolf R. Rhomberg, 1973. "International trade: Price competitiveness in export trade among industrial countries." American Economic Review, May, 63 (2): 412-418.

Keegan, Warren J., 1974. "Multinational scanning: a study of the information sources utilized by headquarters executives in multinational companies." Administrative Science Quarterly, September: 411-421.

Kobrin, Stephen J. 1991. "An empirical analysis of the determinants of global integration." Strategic Management Journal, 12: 17-31.

Kogut, Bruce. 1983. "Foreign direct investment as a sequential process." In Kindleberger, Charles P. and David B. Audtresch (eds.). The Multinational Corporation in the 1980s, Cambridge, MA: The MIT Press (38-56).

Krugman, Paul R., and Richard E. Baldwin, 1987. "The persistence of the U.S. trade deficit." Brookings Papers on Economic Activity, 1: 1-55.

Krugman, Paul, 1995. "Increasing returns, imperfect competition and the positive theory of international trade." In Grossman, Gene, and Kenneth Rogoff (eds.). Handbook of International Economics: Vol. III. North Holland: Elsevier Science Publishers B.V.

Lawrence, Robert Z., 1990. "U.S. current account adjustment: An appraisal." Brookings Papers on Economic Activity, 2: 343-392. 
Leamer, Edward E., and James Levinsohn, 1995. "International Trade Theory: The evidence." In Grossman, Gene, and Kenneth Rogoff (eds.). Handbook of International Economics: Vol. III. North Holland: Elsevier Science Publishers B.V.

Lessard, Donald R., 1986. "Finance and global competition: exploiting financial scope and coping with volatile exchange rates." In Porter, Michael E., editor. Competition in Global Industries. Boston: Harvard Business School Press (147-184).

Liang, Neng and Arvind Parkhe, 1997. "Importer behavior: the neglected counterpart of international exchange." Journal of International Business Studies, Third Quarter: 495-530.

Liang, Neng and Rodney L. Stump, 1996. "Cognitive heuristics in overseas vendor search and evaluation: A proposed model of importer buying behavior." International Executive, 38 (6): 779-806.

Martin, Xavier, Will Mitchell, and Anand Swaminathan, 1995. "Recreating and extending Japanese automobile buyer-supplier links in North America." Strategic Management Journal, 16: 589-619.

McCallum, John, 1995. "National borders matter: Canada-U.S. regional trade patterns." American Economic Review, June, 85 (3): 615-623.

Min, Hokey and William P. Galle, 1991. "International purchasing strategies of multinational U.S. firms." International Journal of Purchasing and Materials Management, 2: 9-18.

Organization for Economic Co-operation and Development, 1997. Globalisation and small and medium enterprises, Vols. 1 and 2, Paris: OECD.

Prahalad, C. K. and Yves L. Doz, 1987. The multinational mission. New York: The Free Press.

Rangan, Subramanian, 1998. "The problem of search and deliberation in economic action: When networks really matter," unpublished INSEAD working paper, Fontainebleau, France.

Rangan, Subramanian and Robert Z. Lawrence, 1999. A prism on globalization: Corporate responses to the dollar, Washington, D. C.: Brookings Institution.

Rauch, James E., 1997. "Networks versus markets in international trade." Working paper, Department of Economics, University of California, San Diego, La Jolla, CA, and National Bureau of Economic Research, Cambridge, MA, USA.

Stern, Robert M., Jonathan Francis, and Bruce Schumacher, 1976. Price elasticities in international trade: An annotated bibliography. London: The Macmillan Press.

Stigler, George J., 1961. "The economics of information." The Journal of Political Economy, June, 69 (3): 213-225. 
Uzzi, Brian, 1997. "Social structure and competition in interfirm networks: The paradox of embeddedness." Administrative Science Quarterly, March, 42: 35-67

Vernon, Raymond, 1966. "International investment and international trade in the product cycle.” Quarterly Journal of Economics, May, 80 (2): 190-207.

Vernon, Raymond, 1979. "The product hypothesis in a new international environment." Oxford Bulletin of Economics and Statistics, 41: 255-267.

Webster, Frederick E., Jr., and Yoram Wind, 1972. Organizational Buying Behavior. Englewood Cliffs, New Jersey: Prentice-Hall.

Wei, Shang-Jin, 1996. "Intra-national versus international trade: How stubborn are nations in global integration?" Working paper, National Bureau of Economic Research, April, Paper No. 5531.

Williamson, Oliver E., 1975. Markets and Hierarchies: Analysis and antitrust implications. London, England: The Free Press, Collier Macmillan.

Williamson, Peter J., 1986. "Multinational enterprise behavior and domestic industry adjustment under import threat." The Review of Economics and Statistics, August, LXVIII (3): 359-368. 
25 
Table 1. Regressions explaining U.S. manufacturing imports in food, chemicals, machinery, and electrical products, from selected countries, 1977-94

\begin{tabular}{|c|c|c|c|c|c|c|}
\hline Independent variables & $\begin{array}{c}\text { U.S. } \\
\text { Overall } \\
\text { (1) }\end{array}$ & $\begin{array}{c}M N E \\
(2)\end{array}$ & $\begin{array}{c}\text { U.S. } \\
\text { Overall } \\
\text { (3) }\end{array}$ & $\begin{array}{c}M N E \\
\text { (4) }\end{array}$ & $\begin{array}{c}\text { U.S. } \\
\text { Overall } \\
(5)\end{array}$ & $\begin{array}{c}M N E \\
(6)\end{array}$ \\
\hline Constant & $\begin{array}{l}-6.93 * * * \\
(1.41)\end{array}$ & $\begin{array}{l}-9.14 * * * \\
(2.40)\end{array}$ & $\begin{array}{r}-0.85 \\
(2.50)\end{array}$ & $\begin{array}{r}-2.59 \\
(3.44)\end{array}$ & $\begin{array}{r}-1.48 \\
(2.64)\end{array}$ & $\begin{array}{r}-3.79 \\
(3.49)\end{array}$ \\
\hline U.S. industry GDP & $\begin{array}{l}2.33^{* * *} \\
(0.20)\end{array}$ & $\begin{array}{l}1.99^{* * *} \\
(0.35)^{2}\end{array}$ & $\begin{array}{l}0.92 * \\
(0.50)\end{array}$ & $\begin{array}{r}0.54 \\
(0.66)\end{array}$ & $\begin{array}{l}0.84^{*} \\
(0.50)\end{array}$ & $\begin{array}{r}0.45 \\
(0.66)\end{array}$ \\
\hline Real exchange rate & $\begin{array}{r}0.24 \\
(0.37)\end{array}$ & $\begin{array}{l}2.60 * * * \\
(0.91)\end{array}$ & $\begin{array}{r}0.07 \\
(0.47)\end{array}$ & $\begin{array}{l}2.87^{* * *} \\
(0.96)\end{array}$ & $\begin{array}{r}0.33 \\
(0.52)\end{array}$ & $\begin{array}{l}3.42 * * * \\
(1.00)\end{array}$ \\
\hline $\begin{array}{l}\text { 1-year lagged real } \\
\text { exchange rate }\end{array}$ & & & $\begin{array}{l}0.69 * * \\
(0.33)\end{array}$ & $\begin{array}{l}0.96^{*} \\
(0.52)\end{array}$ & $\begin{array}{r}-0.10 \\
(0.52)\end{array}$ & $\begin{array}{r}0.03 \\
(0.72)\end{array}$ \\
\hline $\begin{array}{l}\text { 2-year lagged real } \\
\text { exchange rate }\end{array}$ & & & & & $\begin{array}{l}0.74 * * \\
(0.36)\end{array}$ & $\begin{array}{l}0.86 * * \\
(0.47)\end{array}$ \\
\hline Time & & & $\begin{array}{l}0.05 * * * \\
(0.02)\end{array}$ & $\begin{array}{r}0.04 \\
(0.03)\end{array}$ & $\begin{array}{l}0.05^{* * *} \\
(0.02)\end{array}$ & $\begin{array}{r}0.04 \\
(0.03)\end{array}$ \\
\hline $\begin{array}{l}\text { Firm size* Real } \\
\text { exchange rate }\end{array}$ & $\begin{array}{r}0.05 \\
(0.05)\end{array}$ & $\begin{array}{l}-0.17^{* *} \\
(0.08)\end{array}$ & $\begin{array}{r}-0.01 \\
(0.05)\end{array}$ & $\begin{array}{l}-0.30^{* * *} \\
(0.09)\end{array}$ & $\begin{array}{r}-0.01 \\
(0.06)\end{array}$ & $\begin{array}{l}-0.31 \text { *** } \\
(0.08)\end{array}$ \\
\hline Chemical products & $\begin{array}{l}-0.53 * * \\
(0.22)\end{array}$ & $\begin{array}{l}-0.36 * * \\
(0.17)\end{array}$ & $\begin{array}{r}-0.24 \\
(0.25)\end{array}$ & $\begin{array}{r}-0.14 \\
(0.18)\end{array}$ & $\begin{array}{r}-0.27 \\
(0.26)\end{array}$ & $\begin{array}{r}-0.12 \\
(0.17)\end{array}$ \\
\hline Food products & $\begin{array}{l}-0.77^{* * *} \\
(0.21)\end{array}$ & $\begin{array}{l}-0.77^{*} \\
(0.42)\end{array}$ & $\begin{array}{l}-0.76 * * * \\
(0.22)\end{array}$ & $\begin{array}{r}-0.37 \\
(0.45)\end{array}$ & $\begin{array}{l}-0.83 * * * \\
(0.25)\end{array}$ & $\begin{array}{r}-0.33 \\
(0.45)\end{array}$ \\
\hline Electrical products & $\begin{array}{l}-1.24 * * * \\
(0.15)\end{array}$ & $\begin{array}{l}-1.15^{* * *} \\
(0.22)\end{array}$ & $\begin{array}{l}-0.92 * * * \\
(0.18)\end{array}$ & $\begin{array}{l}-0.70^{* * *} \\
(0.24)\end{array}$ & $\begin{array}{l}-0.92 * * * \\
(0.19)\end{array}$ & $\begin{array}{l}-0.68^{* * *} \\
(0.24)\end{array}$ \\
\hline $\begin{array}{l}\text { Country } \\
\text { dummies }\end{array}$ & Yes & Yes & Yes & Yes & Yes & Yes \\
\hline No. of observations & 648 & 361 & 612 & 339 & 576 & 339 \\
\hline Adj. $R^{2}$ & 0.61 & 0.77 & 0.61 & 0.78 & 0.61 & 0.78 \\
\hline$F$-stat & $73.40 * * *$ & $87.60^{* * * *}$ & $61.28 * * *$ & $73.60 * * *$ & $54.42 * * *$ & $69.98 * * *$ \\
\hline
\end{tabular}

Notes: ${ }^{*}, * *$, and $* * *$ indicate significance at the $10 \%, 5 \%$, and $1 \%$ levels respectively. Regressions are based upon annual data. All variables (except the time trend and the country and industry dummies) are entered in their natural logs. The dependent variable is U.S. industry-country-year specific import values. Exchange rates are also industry-country-year specific. U.S. GDP is industry-and-year specific. Firm size is measured in terms of average employees per firm in the U.S. and is industry-and-year specific. Coverage is limited to the following nine U.S. trade partners: Australia, Canada, France, Germany, Italy, Japan, Netherlands, Switzerland, and the United Kingdom. 
Table 2. Pooled regressions explaining U.S. manufacturing imports in food, chemicals, machinery, and electrical products, from selected countries, 1977-94

\begin{tabular}{|c|c|c|c|c|}
\hline \multirow[b]{3}{*}{ Variable } & \multicolumn{4}{|c|}{ U.S. Overall and MNE pooled } \\
\hline & $\begin{array}{c}\text { All } \\
\text { available } \\
\text { observations }\end{array}$ & $\begin{array}{l}\text { Without } \\
\text { Australia, } \\
\text { Italy, and } \\
\text { Switzerland }\end{array}$ & $\begin{array}{c}\text { Without } \\
\text { Australia, } \\
\text { Italy, and } \\
\text { Switzerland }\end{array}$ & $\begin{array}{c}\text { All } \\
\text { available } \\
\text { observations }\end{array}$ \\
\hline & (1) & (2) & (3) & (4) \\
\hline \multirow[t]{2}{*}{ U.S. industry GDP } & $2.16 * * *$ & $2.39 * * *$ & $2.23^{* * *}$ & $1.96 * * *$ \\
\hline & $(0.18)$ & $(0.19)$ & $(0.21)$ & $(0.19)$ \\
\hline \multirow[t]{2}{*}{ Real exchange rate } & $0.65 * *$ & $0.79 * *$ & $0.72 * *$ & $0.57 *$ \\
\hline & $(0.33)$ & $(0.35)$ & $(0.35)$ & $(0.33)$ \\
\hline \multirow{2}{*}{$\begin{array}{l}\text { Firm size*Real exchange } \\
\text { rate }\end{array}$} & -0.05 & $-0.06 *$ & -0.06 & -0.04 \\
\hline & $(0.03)$ & $(0.04)$ & $(0.04)$ & $(0.03)$ \\
\hline \multirow[t]{2}{*}{ MNE } & $-7.53 * * *$ & $-10.96 * * *$ & $-14.34 * * *$ & $-11.83 * * *$ \\
\hline & $(1.68)$ & $(1.81)$ & $(2.67)$ & $(2.48)$ \\
\hline \multirow{2}{*}{$\begin{array}{l}\text { MNE*Real } \\
\text { exchange rate }\end{array}$} & $1.23 * * *$ & $2.09 * * *$ & $2.24 * * *$ & $1.42 * * *$ \\
\hline & $(0.39)$ & $(0.42)$ & $(0.43)$ & $(0.40)$ \\
\hline \multirow{2}{*}{$\begin{array}{l}\text { MNE*U.S. } \\
\text { industry GDP }\end{array}$} & & & $0.51 *$ & $0.65 * *$ \\
\hline & & & $(0.30)$ & $(0.28)$ \\
\hline \multirow{2}{*}{$\begin{array}{l}\text { Country and industry } \\
\text { dummies }\end{array}$} & & & & \\
\hline & Yes & Yes & Yes & Yes \\
\hline No. of observations & 1,009 & 685 & 685 & 1,009 \\
\hline Adj. $R^{2}$ & 0.73 & 0.73 & 0.73 & 0.73 \\
\hline$F$-stat & $172.28 * * *$ & $141.45^{* * *}$ & $131.94 * * *$ & $163.22 * * *$ \\
\hline
\end{tabular}


Table 3. Interacting time and exchange rates in pooled regressions explaining U.S. manufacturing imports in food, chemicals, machinery, and electrical products, from selected countries, 1977-94

\begin{tabular}{|c|c|c|c|c|}
\hline \multirow[b]{2}{*}{ Independent variables } & \multicolumn{4}{|c|}{ U.S. Overall and $M N E$ pooled } \\
\hline & (1) & $(2)$ & (3) & (4) \\
\hline U.S. industry GDP & $\begin{array}{l}1.06 * * * \\
(0.41)\end{array}$ & $\begin{array}{l}0.95^{* *} \\
(0.42)\end{array}$ & ${ }^{1.01}{ }^{* *}$ & $\begin{array}{l}0.92 * * \\
(0.42)\end{array}$ \\
\hline Real exchange rate & $\begin{array}{l}0.78^{* *} \\
(0.33)\end{array}$ & $\begin{array}{l}0.77^{* *} \\
(0.33)\end{array}$ & $\begin{array}{r}0.14 \\
(0.46)\end{array}$ & $\begin{array}{r}0.21 \\
(0.47)\end{array}$ \\
\hline Firm size*Real exchange rate & $\begin{array}{l}-0.07 * * \\
(0.04)\end{array}$ & $\begin{array}{l}-0.07^{* *} \\
(0.04)\end{array}$ & $\begin{array}{l}-0.07 * * \\
(0.04)\end{array}$ & $\begin{array}{l}-0.07 * * \\
(0.04)\end{array}$ \\
\hline Time & $\begin{array}{l}0.05 * * * \\
(0.02)\end{array}$ & $\begin{array}{l}0.05^{* * *} \\
(0.02)\end{array}$ & $\begin{array}{l}-0.28^{*} \\
(0.17)\end{array}$ & $\begin{array}{r}-0.24 \\
(0.17)\end{array}$ \\
\hline MNE & $\begin{array}{l}-7.91 * * * \\
(1.68)\end{array}$ & $\begin{array}{l}-8.81 * * * \\
(1.75)\end{array}$ & $\begin{array}{l}-7.41 * * * \\
(1.70)\end{array}$ & $\begin{array}{l}-8.24 * * * \\
(1.78)\end{array}$ \\
\hline MNE*Real exchange rate & $\begin{array}{l}1.37^{* * *} \\
(0.39)\end{array}$ & $\begin{array}{l}1.50 * * * \\
(0.40)\end{array}$ & $\begin{array}{l}1.26 * * * \\
(0.40)\end{array}$ & $\begin{array}{l}1.39 * * * \\
(0.40)\end{array}$ \\
\hline MNE*Real exchange rate*Time & & $\begin{array}{l}0.01 * \\
(0.00)\end{array}$ & & $\begin{array}{r}0.01 \\
(0.00)\end{array}$ \\
\hline Real exchange rate*Time & & & $\begin{array}{l}0.08^{* *} \\
(0.04)\end{array}$ & $\begin{array}{l}0.07 * \\
(0.04)\end{array}$ \\
\hline $\begin{array}{l}\text { Country and industry } \\
\text { dummies }\end{array}$ & Yes & Yes & Yes & Yes \\
\hline No. of observations & 1,009 & 1,009 & 1,009 & 1,009 \\
\hline Adj. $R^{2}$ & 0.73 & 0.73 & 0.74 & 0.73 \\
\hline$F$-stat & $163.90 * * *$ & $155.33 * * *$ & $155.45^{* * *}$ & $147.59 * * *$ \\
\hline
\end{tabular}


Table 4. European single market's importance to development of firm strategy

\begin{tabular}{|c|c|c|c|c|c|c|c|c|}
\hline \multirow{2}{*}{$\begin{array}{l}\text { Purchase from } \\
\text { other } E U \\
\text { markets of: }\end{array}$} & \multicolumn{4}{|c|}{$\begin{array}{c}\text { Percentage of enterprises expressing } \\
\text { opinion }\end{array}$} & \multicolumn{4}{|c|}{$\begin{array}{c}\text { Percentage of enterprises offering } \\
\text { opinion expressed in number of } \\
\text { salaried employees }\end{array}$} \\
\hline & $\begin{array}{c}\text { Very } \\
\text { important }\end{array}$ & $\begin{array}{c}\text { Quite } \\
\text { important }\end{array}$ & $\begin{array}{c}\text { Not } \\
\text { important }\end{array}$ & $\begin{array}{l}\text { Don't } \\
\text { know }\end{array}$ & $\begin{array}{c}\text { Very } \\
\text { important }\end{array}$ & $\begin{array}{c}\text { Quite } \\
\text { important }\end{array}$ & $\begin{array}{c}\text { Not } \\
\text { imporrant }\end{array}$ & $\begin{array}{l}\text { Don't } \\
\text { know }\end{array}$ \\
\hline Raw materials & 10 & 24 & 48 & 19 & 11 & 31 & 45 & 13 \\
\hline Components & 7 & 18 & 52 & 24 & 8 & 25 & 51 & 16 \\
\hline Business services & 2 & 7 & 60 & 31 & 2 & 11 & 65 & 22 \\
\hline Financial services & 1 & 6 & 58 & 35 & 2 & 10 & 62 & 25 \\
\hline
\end{tabular}

Source: The European Commission, 1997. The single market review: Results of the business survey, Luxembourg: Office for Official Publications of the European Communities, Table EUR M.3, pg. 23. 
Figure 1. Schematic mapping selected areas of international economic activity against search and deliberation problems

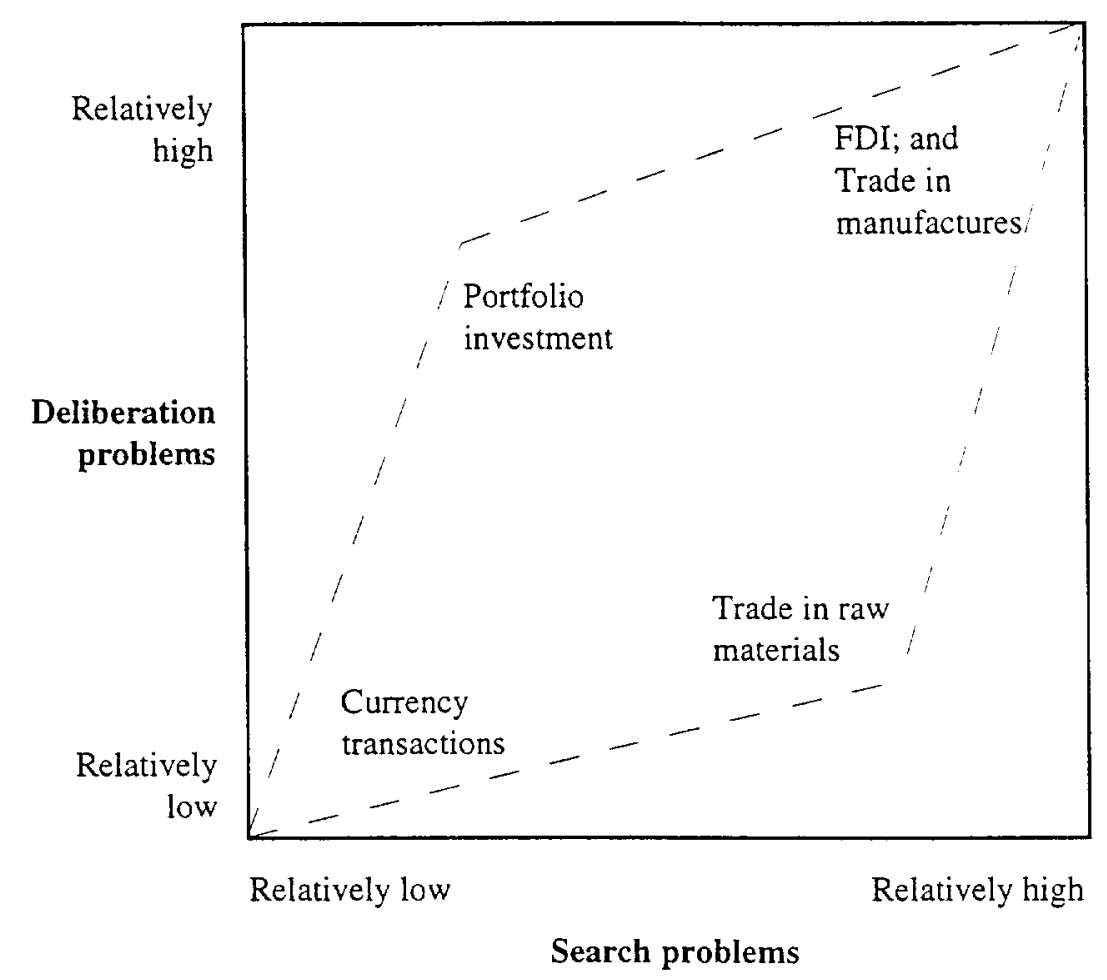

